\title{
IMPROVEMENT OF THE THEORY OF MODELLING THE AMINO ACID CONTENT OF PLANT GREEN MASS HALF- PRODUCTS
}

\author{
V. Huts, G. Simakhina, L. Solodko \\ National University of Food Technologies
}

\begin{tabular}{|c|c|}
\hline Key words: & ABSTRACT \\
\hline $\begin{array}{l}\text { Proteinaceous half- } \\
\text { Products } \\
\text { Quality modeling } \\
\text { Recipe optimization } \\
\text { Plant green mass } \\
\text { Amino acids }\end{array}$ & \multirow{3}{*}{$\begin{array}{l}\text { The literary data and the results of our own researches } \\
\text { became a basis for this article to prove the possibility of } \\
\text { solving the problem of protein deficit in diets of population } \\
\text { by optimizing the protein component in recipes of final } \\
\text { products. The authors proposed the modified theory to mo- } \\
\text { del the amino acid content for green mass of agricultural and } \\
\text { wild plants like red and sugar beets, carrot, nettle, ramsons } \\
\text { etc. There were established the parameters of the area of } \\
\text { quality profile for an ideal protein in conditions that the } \\
\text { score for all of the indispensable amino acids is equal to } 1 \text {. } \\
\text { The proposed model allows creating the composites with } \\
\text { well-balanced amino acid content on the base of green mass } \\
\text { half-products, which will furthermore solve the important } \\
\text { social and economical task in the sphere of food technologies. }\end{array}$} \\
\hline $\begin{array}{l}\quad \text { Article history: } \\
\text { Received } 12.05 .2017 \\
\text { Received in revised form } \\
03.06 .2017 \\
\text { Accepted } 24.06 .2017\end{array}$ & \\
\hline $\begin{array}{l}\text { Corresponding author: } \\
\text { G. Simakhina } \\
\text { E-mail: } \\
\text { npnuht@ukr.net }\end{array}$ & \\
\hline
\end{tabular}

DOI: $10.24263 / 2225-2924-2017-23-4-32$

\section{ВДОСКОНАЛЕННЯ ТЕОРІЇ МОДЕЛЮВАННЯ АМІНОКИСЛОТНОГО СКЛАДУ НАПІВФАБРИКАТІВ ІЗ ЗЕЛЕНОї МАСИ РОСЛИН}

\author{
В.С. Гуць, Г.О. Сімахіна, Л.М. Солодко \\ Національний університет харчових технологій
}

На основі літературних даних і власних досліджень у статті обтрунтовано можливість вирішення проблеми білкового дефіциту в раціонах харчування населення шляхом підвищення біологічної цінності рослинних білків унаслідок оптимізаиії протеїнової складової в рецептурах готових продуктів. Запропоновано вдосконалену теорію моделювання амінокислотного складу білкових напівфабрикатів із зеленої маси сільськогосподарських і дикорослих рослин иукрового та столового буряків, моркви, портулаку, черемші тощо. Встановлено величину площі профілю якості для ідеального білка за умови, щэо для всіх незамінних амінокислот скор становить одиницю. Запропонована модель дасть змогу створювати на основі напівфабрикатів із зеленої маси рослин композити зі збалансованим амінокислотним складом, що вирімує важливе соиіально-економічне завдання у сфері харчових технологій. 
Ключові слова: білковмісні напівфабрикати, моделювання якості, оптимізачія рецептури, зелена маса, амінокислоти.

Постановка проблеми. У багатьох країнах світу населення страждає від нестачі білка в харчових продуктах. Його дефіцит шкідливо впливає на організм людини: знижує захисні функції організму, формує синдром хронічної втоми, погіршує розумові і фізичні можливості, прискорює процес старіння $[1 ; 2]$. Тільки вживання збалансованої за хімічним складом, багатої на білок їжі дасть змогу зберегти здоров'я і високу працездатність нашим співвітчизникам, буде сприяти здоровому росту молодого покоління.

Світове виробництво тваринних білків у сучасних умовах швидкого зростання населення значною мірою вичерпало свої можливості. Проблему білкової нестачі можна вирішити кількома шляхами: використанням нових джерел білка (білків сої, зеленої маси рослин, мікроорганізмів, одноклітинних і багатоклітинних водоростей, шротів олійних культур тощо); збільшенням біологічної цінності рослинних білків шляхом збагачення харчових продуктів амінокислотами; взаємним білковим збагаченням шляхом додавання до суміші рослинних білків тваринних протеїнів - білків молока, побічних продуктів молочного виробництва тощо [3; 4]. У зв'язку з цим актуальним $\epsilon$ проведення наукових досліджень для оптимізації білкової складової сировини для виробництва нових продуктів із використанням білковмісних рослинних напівфабрикатів.

Використання нових білковмісних напівфабрикатів із зеленої маси рослин у виробництві харчових продуктів дасть можливість розширити їх асортимент, забезпечити матеріальний і енергетичний баланс організму, оптимізувати білковий склад продукту, що приведе до підвищення його харчової цінності з одночасною гарантією якості.

Мета дослідження: моделювання амінокислотного складу напівфабрикатів із зеленої маси рослин і вдосконалення теорії прогнозування якості їхньої білкової складової.

Матеріали і методи. Матеріалами для проведення досліджень $є$ напівфабрикати, отримані із зеленої маси сільськогосподарських і дикорослих рослин, рецептури нових видів напівфабрикатів.

Масову частку амінокислот визначали іонообмінною рідинно-колончастою хроматографією на автоматичному аналізаторі Т339 («Мікротехна», Чехія), триптофану - колориметричним методом із попереднім лужним гідролізом [5].

Викладення основних результатів дослідження. Порошкоподібні білковмісні напівфабрикати із висушеної зеленої маси рослин $є$ складною полікомпонентною системою, що відзначається високим вмістом біологічно активних речовин, і тому, враховуючи дефіцит білка, виникає складність у використанні їх як комплексних натуральних збагачувачів різноманітних харчових середовищ. Крім того, порошкові білковмісні напівфабрикати можна застосовувати як сировину для отримання харчових барвників, а також як компоненти для створення нових продуктів спеціального лікувально-профілактичного призначення зі збалансованим амінокислотним складом. Аналітичними дослі- 
дженнями доведено перспективність [6] використання на харчові цілі надземної частини цукрових і столових буряків, листя моркви, кропиви та черемші, вегетативної частини портулаку городнього. Водночас потребує наукового обгрунтування складання сумішей в оптимальних співвідношеннях у вигляді порошкоподібних білковмісних напівфабрикатів для кулінарних виробів $\mathrm{i}$ протеїново-вітамінних композитів поліфункціональної дії на їхній основі.

Ефективність засвоєння білка організмом людини безпосередньо залежить від його кількості і біологічної цінності. Тому першочерговим завданням моделювання i оптимізації амінокислотного складу напівфабрикатів із зеленої маси рослин $є$ визначення достатньої для його засвоєння організмом людини кількості та біологічної цінності компонентів білковмісних сумішей. Біологічна цінність білку визначається його якістю, насамперед амінокислотним складом і швидкістю розщеплення протеолітичними ферментами травної системи. В технології харчових продуктів широко використовують хімічні та біологічні методи визначення біологічної цінності білку [5].

Як хімічний використовують метод розрахунку амінокислотного скору, що полягає в обчисленні процентного вмісту амінокислот щодо вмісту їх у білку, прийнятому за ідеальний. Величина амінокислотного скору дає змогу встановити, за вмістом яких незамінних амінокислот білок досліджуваного продукту не відповідає визначеним оптимальним нормам [7].

Метод розрахунку амінокислотного скору покладено в основу проектування комбінованих харчових продуктів повноцінного білкового складу. Як правило, у більшості харчових продуктів набір білковмісних інгредієнтів 3 незамінних амінокислот не повністю забезпечує максимально збалансований стосовно ідеального білкового еталону амінокислотний склад. Застосування в рецептурі харчових продуктів напівфабрикатів із зеленої маси рослин дасть можливість використати цінний білок різних рослин для максимального наближення харчових продуктів до показників оптимального білкового складу еталона.

У табл. 1 представлено результати експериментальних досліджень амінокислотного скору для зразків висушеної рослинної сировини.

Таблиия 1. Амінокислотний скор зразків висушеної рослинної сировини, \%

\begin{tabular}{|c|c|c|c|c|c|c|}
\hline Показники & $\begin{array}{c}\text { Цукровий } \\
\text { буряк }\end{array}$ & $\begin{array}{c}\text { Столовий } \\
\text { буряк }\end{array}$ & Морква & Портулак & Кропива & Черемша \\
\hline Лізин & 101,3 & 118,5 & 121,3 & 109,6 & 99,1 & 102,9 \\
\hline Треонін & 118,75 & 113,25 & 127,5 & 101,75 & 122,5 & 110,25 \\
\hline Валін & 113,6 & 110,4 & 101,4 & 115 & 109,4 & 70 \\
\hline $\begin{array}{c}\text { Метіонін + } \\
\text { цистин }\end{array}$ & 109 & 101,7 & 92,6 & 48,9 & 80,3 & 114 \\
\hline Ізолейцин & 78,75 & 80,5 & 76,5 & 77,75 & 76,75 & 169,75 \\
\hline Лейцин & 135 & 158 & 127 & 114 & 131 & 63 \\
\hline $\begin{array}{c}\text { Фенілаланін + } \\
\text { тирозин }\end{array}$ & 181,2 & 168,5 & 161,5 & 146 & 162 & 121 \\
\hline Триптофан & 107 & 102 & 130 & 123 & 168 & 137 \\
\hline
\end{tabular}


Аналіз результатів досліджень, представлених у табл. 1, засвідчив, що у всіх зразків рослинної сировини амінокислотний скор не відповідає вимогам ідеального білка - як за дефіцитом, так і за надлишковим вмістом.

Амінокислота ізолейцин лімітована для цукрового $(78,5 \%)$ і столового буряку (80,5\%), моркви (76,5\%), портулаку $(77,75 \%)$, кропиви $(76,75 \%)$. Однак має місце iї значний надлишок для черемші (169,75\%). Протилежний результат маємо для амінокислоти лейцину. Вона лімітована лише у черемші (63\%), а для інших зразків рослинної сировини - надлишкова. Для столового буряку надлишок досягає $158 \%$. Найбільший надлишок $(181,2)$ має амінокислота фенілаланін + тирозин цукрового буряку.

Існуючі методи моделювання амінокислотного складу практично не враховують одночасного впливу надлишку і дефіциту амінокислоти на загальний білковий баланс харчових дисперсних систем. У цьому випадку надлишок, як правило, не враховується. Для отримання економічно і функціонально науково обгрунтованих білковмісних сумішей із зеленої маси рослин 3 оптимально збалансованим амінокислотним складом необхідно провести підбір комбінацій окремих порошків із висушеної рослинної сировини 3 урахуванням як дефіциту, так і надлишку незамінних амінокислот.

У [8] рекомендовано робити підбір і складати рецептуру сумішей з використанням методів математичного моделювання на основі критерію повноцінності. Недоліком цього методу є створення композицій, які вважаються оптимальними за збалансованим за дефіцитом амінокислотним складом. Така оптимізація відноситься тільки до лімітованої незамінної амінокислоти без урахування надлишків для інших, скор яких може досягти до 200\%. Відомо, що значні надлишки можуть негативно впливати не тільки на економію сировини, а й на складові якості продукту, обмежувати його лікувальнопрофілактичне використання. Крім того, підбір композицій повинен здійснюватись так, щоб вони мали необхідні органолептичні характеристики. Наприклад, характерний для харчових продуктів колір, запах і смак. Так, для отримання приємного присмаку часнику обов'язковим $є$ використання в складі композиції сухого порошку черемші тільки в оптимальній кількості. Для отримання приємного кольору традиційно використовують барвники 3 рослинної сировини, наприклад, посилення червоного забарвлення можна досягти, додаючи порошок зі столового буряку, а завдяки хлорофілу, який міститься в листі кропиви або зеленій масі буряків, можна отримати зелене забарвлення різної інтенсивності.

Складові показників окремих порошків рослинної сировини в рекомендованих комбінованих продуктах наведено в табл. 2.

Таблиия 2. Складники композицій зі збалансованим вмістом амінокислот, \% до маси

\begin{tabular}{|c|c|c|c|c|}
\hline $\begin{array}{c}\text { Вихідна } \\
\text { сировина }\end{array}$ & Композиція № 1 & Композиція № 2 & Композиція № 3 & Композиція № 4 \\
\hline Цукровий буряк & $48 \pm 0,5$ & $69 \pm 5,0$ & $35 \pm 0,5$ & - \\
\hline Столовий буряк & - & - & - & $77 \pm 1,5$ \\
\hline Портулак & $15 \pm 0,5$ & - & - & - \\
\hline Кропива & - & - & $35 \pm 0,5$ & - \\
\hline Черемша & $37 \pm 0,5$ & $31 \pm 5,0$ & $30 \pm 0,5$ & $23 \pm 1,5$ \\
\hline
\end{tabular}


На нашу думку, отримані білкові композиції можуть бути використані як білковий збагачувач рослинного походження для комбінованих продуктів спеціального та лікувально-профілактичного призначення, а також при створенні збалансованих за харчовою цінністю продуктів, у зв'язку зі значним надлишком окремих амінокислот у загальному амінокислотному балансі. Так, значна кількість черемші може негативно впливати на смакові якості харчових продуктів унаслідок специфічного присмаку часнику.

Крім того, як недолік отриманих композицій слід зазначити обмежене використання окремих порошків. Так, у композиції № 2 використано тільки цукровий буряк (69\%) і черемшу (31\%), а в композиції № $4-$ столовий буряк $(77 \%)$ і черемшу (23\%). Це теж може обмежувати використання композицій, виходячи з отримання необхідних органолептичних показників деяких харчових продуктів. Тому потребує подальшої оптимізації їхній амінокислотний скор (табл. 3).

Таблиця 3. Амінокислотний скор композицій зі збалансованим вмістом амінокислот, \%

\begin{tabular}{|c|c|c|c|c|}
\hline Показники & Композиція № 1 & Композиція № 2 & Композиція № 3 & Композиція № 4 \\
\hline Лізин & 103,3 & 102,5 & 100,9 & 114,9 \\
\hline Треонін & 113,0 & 116,5 & 117,8 & 112,5 \\
\hline Валін & 100,0 & 101,6 & 100,2 & 101,0 \\
\hline Метіонін + цистин & 100,0 & 110,0 & 100,6 & 104,6 \\
\hline Ізолейцин & 107,8 & 102,5 & 103,3 & 101,3 \\
\hline Лейцин & 108,0 & 115,7 & 113,7 & 136,3 \\
\hline $\begin{array}{c}\text { Фенілаланін + } \\
\text { тирозин }\end{array}$ & 155,3 & 164,5 & 158,0 & 157,5 \\
\hline Триптофан & 120,0 & 116,0 & 136,0 & 110,0 \\
\hline
\end{tabular}

Аналіз результатів показує значне перевищення для ряду композиції скору амінокислот: фенілаланін + тирозин (164\%) та триптофан (136\%).

У табл. 4 та 5 наведено величини коефіцієнтів порівняльної надлишковості незамінних амінокислот у сухих рослинних порошках i композиціях iз збалансованим вмістом амінокислот.

Таблиця 4. Коефіціснти порівняльної надлишковості незамінних амінокислот у сухих рослинних порошках

\begin{tabular}{|c|c|c|c|c|c|c|}
\hline $\begin{array}{c}\text { Коефіцієнт } \\
\text { порівняльної } \\
\text { надлишковості }\end{array}$ & $\begin{array}{c}\text { Цукровий } \\
\text { буряк }\end{array}$ & $\begin{array}{c}\text { Столовий } \\
\text { буряк }\end{array}$ & Портулак & Кропива & Черемша & Морква \\
\hline$\sigma, \%$ & 20,34 & 21,78 & 42,64 & 18,96 & 23,35 & 22,24 \\
\hline
\end{tabular}

Аналіз даних табл. 4 свідчить про доцільність зменшення коефіцієнта порівняльної надлишковості при складанні композицій.

Таблиия 5. Коефіціснти порівняльної надлишковості незамінних амінокислот у композиціях зі збалансованим вмістом амінокислот

\begin{tabular}{|c|c|c|c|c|}
\hline $\begin{array}{c}\text { Коефіцієнт } \\
\text { порівняльної } \\
\text { надлишковості }\end{array}$ & Композиція № 1 & Композиція № 2 & Композиція № 3 & Композиція № 4 \\
\hline$\sigma, \%$ & 5,09 & 5,75 & 5,64 & 7,24 \\
\hline
\end{tabular}


3 метою отримання якісного як за органолептичними показниками, так i оптимальної білкової складової продукту проведено вдосконалення теорії моделювання його амінокислотного складу.

Для визначення оптимального складу амінокислотного скору з урахуванням дефіциту і надлишку окремих амінокислот запропоновано новий підхід до оптимізації білкової складової рослинної сировини на основі аналізу їхніх профілів якості за показником нормованого відхилення $\Delta$ (дельта).

Показник нормованого відхилення $\Delta$ як для надлишку, так і дефіциту амінокислоти знаходили як різницю між дійсним значенням скору для відповідної амінокислоти та 100 -відсотковим його значенням без урахування знака різниці. Для аналізу впливу надлишку на загальний амінокислотний баланс $з$ урахуванням органолептичної складової продукту показник нормованого відхилення дробився (зменшувався) $\Delta(0), \Delta(1), \Delta(1 / 2), \Delta(1 / 4), \Delta(1 / 8)$. У табл. 6 наведено результати розрахунку амінокислотного скору для досліджуваної рослинної сировини. Надалі для зручності виконання розрахунків використовували замість відсотків відносні одиниці обчислення скору.

Таблиия 6. Скори амінокислот з урахуванням показника нормованого відхилення нормованого надлишку $\left(C_{\mathrm{K}} \Delta(0), C_{\mathrm{K}} \Delta(1), C_{\mathrm{K}} \Delta(1 / 2), C_{\mathrm{K}} \Delta(1 / 4), C_{\mathrm{K}} \Delta(1 / 8)\right)$

\begin{tabular}{|c|c|c|c|c|c|c|c|c|c|}
\hline \multirow{2}{*}{ 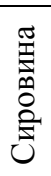 } & \multirow{2}{*}{ 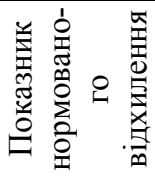 } & \multicolumn{8}{|c|}{ Амінокислота } \\
\hline & & лізин & треонін & валін & $\begin{array}{c}\text { Метіо- } \\
\text { нін + } \\
\text { цистин }\end{array}$ & $\begin{array}{c}\text { Ізолей- } \\
\text { цин }\end{array}$ & $\begin{array}{c}\text { Лей- } \\
\text { цин }\end{array}$ & $\begin{array}{c}\text { Феніл- } \\
\text { аланін + } \\
\text { тирозин }\end{array}$ & $\begin{array}{l}\text { Трип- } \\
\text { тофан }\end{array}$ \\
\hline 1 & 2 & 3 & 4 & 5 & 6 & 7 & 8 & 9 & 10 \\
\hline \multirow{6}{*}{ 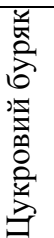 } & $\Delta(0), \%$ & 101,3 & 118,75 & 113,6 & 109 & 78,75 & 135 & 181,2 & 107 \\
\hline & $\Delta(0)$ & 1 & 1 & 1 & 1 & 0,788 & 1 & 1 & 1 \\
\hline & $\Delta(1)$ & 0,987 & 0,8125 & 0,864 & 0,91 & 0,788 & 0,65 & 0,188 & 0,93 \\
\hline & $\Delta(1 / 2)$ & 0,994 & 0,906 & 0,932 & 0,955 & 0,788 & 0,825 & 0,594 & 0,965 \\
\hline & $\Delta(1 / 4)$ & 0,997 & 0,953 & 0,966 & 0,978 & 0,788 & 0,913 & 0,797 & 0,983 \\
\hline & $\Delta(1 / 8)$ & 0,998 & 0,977 & 0,983 & 0,989 & 0,788 & 0,956 & 0,899 & 0,991 \\
\hline \multirow{6}{*}{ 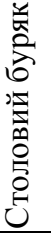 } & $\Delta(0), \%$ & 118,5 & 113,25 & 110,4 & 101,7 & 80,5 & 158 & 168,5 & 102 \\
\hline & $\Delta(0)$ & 1 & 1 & 1 & 1 & 0,805 & 1 & 1 & 1 \\
\hline & $\Delta(1)$ & 0,815 & 0,8675 & 0,896 & 0,983 & 0,805 & 0,42 & 0,315 & 0,98 \\
\hline & $\Delta(1 / 2)$ & 0,909 & 0,934 & 0,948 & 0,992 & 0,805 & 0,71 & 0,658 & 0,99 \\
\hline & $\Delta(1 / 4)$ & 0,954 & 0,967 & 0,974 & 0,996 & 0,805 & 0,855 & 0,829 & 0,95 \\
\hline & $\Delta(1 / 8)$ & 0,977 & 0,983 & 0,987 & 0,998 & 0,805 & 0,928 & 0,914 & 0,98 \\
\hline \multirow{6}{*}{ 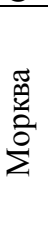 } & $\Delta(0), \%$ & 121,3 & 127,5 & 101,4 & 92,6 & 76,5 & 127 & 161,5 & 130 \\
\hline & $\Delta(0)$ & 1 & 1 & 1 & 0,926 & 0,765 & 1 & 1 & 1 \\
\hline & $\Delta(1)$ & 0,787 & 0,725 & 0,986 & 0,926 & 0,765 & 0,73 & 0,385 & 0,70 \\
\hline & $\Delta(1 / 2)$ & 0,894 & 0,863 & 0,993 & 0,926 & 0,765 & 0,865 & 0,693 & 0,85 \\
\hline & $\Delta(1 / 4)$ & 0,947 & 0,931 & 0,997 & 0,926 & 0,765 & 0,933 & 0,846 & 0,925 \\
\hline & $\Delta(1 / 8)$ & 0,973 & 0,966 & 0,998 & 0,926 & 0,765 & 0,966 & 0,923 & 0,963 \\
\hline \multirow{6}{*}{ 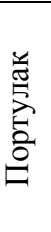 } & $\Delta(0), \%$ & 109,6 & 101,75 & 115 & 48,9 & 77,75 & 114 & 146 & 123 \\
\hline & $\Delta(0)$ & 1 & 1 & 1 & 0,489 & 0,778 & 1 & 1 & 1 \\
\hline & $\Delta(1)$ & 0,904 & 0,9825 & 0,85 & 0,489 & 0,778 & 0,86 & 0,54 & 0,77 \\
\hline & $\Delta(1 / 2)$ & 0,952 & 0,991 & 0,925 & 0,489 & 0,778 & 0,93 & 0,77 & 0,885 \\
\hline & $\Delta(1 / 4)$ & 0,976 & 0,996 & 0,963 & 0,489 & 0,778 & 0,965 & 0,885 & 0,943 \\
\hline & $\Delta(1 / 8)$ & 0,988 & 0,998 & 0,981 & 0,489 & 0,778 & 0,983 & 0,943 & 0,971 \\
\hline
\end{tabular}


Продовження табл. 6

\begin{tabular}{|c|c|c|c|c|c|c|c|c|c|}
\hline 1 & 2 & 3 & 4 & 5 & 6 & 7 & 8 & 9 & 10 \\
\hline \multirow{6}{*}{ 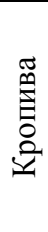 } & $\Delta(0), \%$ & 99,1 & 122,5 & 109,4 & 80,3 & 76,75 & 131 & 162 & 168 \\
\hline & $\Delta(0)$ & 0,991 & 1 & 1 & 0,803 & 0,768 & 1 & 1 & 1 \\
\hline & $\Delta(1)$ & 0,991 & 0,775 & 0,906 & 0,803 & 0,768 & 0,69 & 0,38 & 0,32 \\
\hline & $\Delta(1 / 2)$ & 0,991 & 0,888 & 0,953 & 0,803 & 0,768 & 0,845 & 0,69 & 0,66 \\
\hline & $\Delta(1 / 4)$ & 0,991 & 0,944 & 0,977 & 0,803 & 0,768 & 0,923 & 0,845 & 0,83 \\
\hline & $\Delta(1 / 8)$ & 0,991 & 0,972 & 0,988 & 0,803 & 0,768 & 0,961 & 0,923 & 0,915 \\
\hline \multirow{6}{*}{ 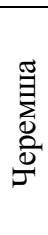 } & $\Delta(0), \%$ & 102,9 & 110,25 & 70 & 114 & 169,75 & 63 & 121 & 137 \\
\hline & $\Delta(0)$ & 1 & 1 & 0,7 & 1 & 1 & 0,63 & 1 & 1 \\
\hline & $\Delta(1)$ & 0,971 & 0,898 & 0,7 & 0,86 & 0,303 & 0,63 & 0,79 & 0,63 \\
\hline & $\Delta(1 / 2)$ & 0,986 & 0,949 & 0,7 & 0,93 & 0,651 & 0,63 & 0,895 & 0,815 \\
\hline & $\Delta(1 / 4)$ & 0,993 & 0,974 & 0,7 & 0,965 & 0,826 & 0,63 & 0,948 & 0,908 \\
\hline & $\Delta(1 / 8)$ & 0,996 & 0,987 & 0,7 & 0,983 & 0,913 & 0,63 & 0,974 & 0,954 \\
\hline
\end{tabular}

Послідовність визначення біологічної цінності рослинної сировини за амінокислотним складом з урахуванням iї надлишку така: спочатку, враховуючи органолептичні характеристики, вибираємо показник нормованого відхилення $\Delta$ від ідеального (100\%) скору кожної незамінної амінокислоти, він дорівнює нулю.

Для $\mathrm{C}_{\mathrm{K}} \Delta(0)$ всі надлишки не враховуємо і вважаємо, що скор надлишкової амінокислоти дорівнює одиниці, а для дефіциту залишаємо дійсним. Наприклад, для цукрового буряку при показнику нормованого відхилення $\Delta(0)$ маємо для амінокислот лізин, треонін, валін, метіонін + цистин, лейцин, фенілаланін + + тирозин, триптофан - скор, що дорівнює $\mathrm{C}_{\mathrm{K}} \Delta(0)=1$. Тільки для ізолейцину він лімітований, тому залишається дійсним 0,788 .

Аналогічно для іншої сировини при $\Delta(0)$ скор лімітованої амінокислоти залишається розрахунковим, тобто незмінним, а для надлишку приймаємо його за 1 . Для того ж цукрового буряку для $\Delta(1)$ скор лімітованої амінокислоти залишається незмінним, а для надлишкової - розраховується за формулою. Наприклад, для лізину:

$$
\mathrm{C}_{\mathrm{K}} \Delta(1)=100-1,3=98,7 \Rightarrow 98,7: 100=0,987 ;
$$

при $\Delta(1 / 2)$ отримаємо:

$$
\mathrm{C}_{\mathrm{K}} \Delta(1 / 2)=100-1,3: 2=100-0,65 \Rightarrow 99,35: 100=0,994 ;
$$

при $\Delta(1 / 4)$ отримаємо:

$$
\mathrm{C}_{\mathrm{K}} \Delta(1 / 4)=100-1,3: 4=100-0,325 \Rightarrow 99,675: 100=0,997 ;
$$

при $\Delta(1 / 8)$ отримаємо:

$$
\mathrm{C}_{\mathrm{K}} \Delta(1 / 8)=100-1,3: 8=100-0,1625 \Rightarrow 99,84: 100=0,998 .
$$

За вищенаведеною методикою розраховано скори амінокислот з урахуванням показника відхилення нормованого надлишку $\Delta(1 / 2), \Delta(1 / 4), \Delta(1 / 8)$ для столового буряку, моркви, портулаку, кропиви, черемші.

Оцінку біологічної цінності сировини з урахуванням вищенаведених розрахункових скорів амінокислот проводили за спеціально розробленою комп’ютерною програмою, яка дала змогу порівняти біологічну цінність різної сировини 3 урахуванням надлишку і дефіциту амінокислот за величиною площі багатокутника (профілю якості). 
При $\Delta(0)$ умовно ідеальної сировини, коли скори всіх незамінних амінокислот приймаємо за 1 (100\%), площа багатокутника дорівнює 2,83 безрозмірних одиниць. Це постійна величина для будь-якої ідеальної сировини. В подальшому рекомендовано використовувати іiі як еталон якості сировини за амінокислотним складом.

Для будь-якої реальної сировини при $\mathrm{C}_{\mathrm{k}} \Delta(0)$, коли всі надлишки не враховуються, а враховується тільки дефіцит амінокислот, площі багатокутників будують менші від $S=2,83$, тобто площі багатокутника, ідеального за амінокислотним складом білку. Для цукрового буряка $S=2,68$, для столового буряка $S=2,69$, для моркви $S=2,62$, для портулаку $S=2,35$, для кропиви $S=2,53$, для черемші $S=2,33$.

\section{Висновки}

Перспективним напрямом використання білковмісних напівфабрикатів із зеленої маси рослин як комплексних збагачувачів різноманітних харчових продуктів $є$ : приготування овочевих страв (таких як різноманітні види овочевої ікри, овочеві соуси, начинки та фарші для пиріжків тощо); м'ясних фаршевих або січених напівфабрикатів; макаронних, хлібобулочних продуктів; майонезів, закусочних паст, соусів, салатних заправок тощо.

Аналіз результатів досліджень показує, що для ідеального білка площа профілю якості, побудованого за умови, коли для всіх незамінних амінокислот скор дорівнює одиниці, буде 2,83 одиниці.

Коли білок за амінокислотним скором не ідеальний, площа профілю якості буде зменшуватись пропорційно дефіциту або надлишку незамінних амінокислот. Для умов $\mathrm{C}_{\mathrm{k}} \Delta(0)$ надлишок не враховуємо (приймаємо за 1 ), а враховуємо тільки дефіцит (приймаємо дійсне значення). Для умов $\mathrm{C}_{\mathrm{K}} \Delta(1), \mathrm{C}_{\mathrm{K}} \Delta(1 / 2)$, $\mathrm{C}_{\mathrm{K}} \Delta(1 / 4), \mathrm{C}_{\mathrm{K}} \Delta(1 / 8)$ враховуємо як дефіцит, так і надлишок.

Впровадження нових теоретичних розробок у моделюванні амінокислотного складу харчових продуктів із додаванням зеленої маси рослин дає можливість оцінити їхню біологічну цінність та 3'ясувати можливості створення на їхній основі оптимальних композитів зі збалансованим амінокислотним складом.

\section{Література}

1. Гігієна харчування з основами нутриціології : підруч. / В.І. Ципріян та ін. - Київ : Здоров'я, 2007. -565 c.

2. Бышевский А.Ш. Биохимия для врача / А.Ш. Бышевский, О.А. Тирсенов. - Екатеринбург : Уральский рабочий, 2003. - $384 \mathrm{c}$.

3. Сімахіна Г.О. Перспективи використання їстівних грибів як джерела білку / Г.О. Сімахіна, І.Ю. Гойко, Н.О. Стеценко // Товари і ринки. - 2014. - № 2. - С. 114-125.

4. Патент UA 93187, МПК А23C 21/00. Спосіб виробництва сухого білково-рослинного напівфабрикату багатофункціонального призначення / Г.О. Сімахіна, І.Ю. Гойко, Н.О. Стеценко ; опубл. 25.09.2014, Бюл. №18.

5. Скурихин И.М. Руководство по методам анализа качества и безопасности пищевых продуктов / И.М. Скурихин, В.А. Тутельян. — Москва : Брандер-Медицина, 1998. — 380 с.

6. Солодко Л.М. Перспективи отримання протеїнових концентратів із зеленої маси рослин / Л.М. Солодко, Г.О. Сімахіна // Наукові праці НУХТ. — 2008. — № 24. - С. 5-10.

7. Бохински Р. Современные воззрения в биохимии : учеб. пособие / Р. Бохински ; пер. с англ. - Москва : Мир, 1997. - 544 с.

8. Липатов Н.Н. Организмические подходы к оценке объектов пищевых производств / Н.Н. Липатов, А.Л. Геворкян // Молочная промышленность. — 2003. — № 3(6). - С. $24-27$. 